\title{
The Marketing Component to Attract Investment in Higher Education: Foreign Experience and Prospects for Russia
}

\author{
Submitted 18/05/20, 1st revision 11/06/20, 2nd revision 20/07/20, accepted 30/07/20
}

\author{
A.A. Maksaev ${ }^{1}$
}

\begin{abstract}
:
Purpose: The article deals with the possibilities of applying foreign experience in activating the marketing component to attract investment in higher education and substantiates an effective mechanism for implementing these prospects in domestic conditions.

Design/Methodology/Approach: The article describes the challenges facing Russian higher education in the transformation into an engine of the national economy innovative development, which involves the activation of fundraising. Also, the author gives examples of American and European positive experience in attracting investment into higher education, describes the size of private funding per person in a number of countries, presents the existing promising models of the development of Russian universities and their needs for partnership with business.

Findings: The influence of state marketing for implementing adaptive changes in higher education appears to be dominant. It is seen as an important factor in creating conditions for investment flows to universities. A mechanism for creating research and educational centres in the regions that operate on the basis of marketing partnerships contributing to the creation of innovative solutions for the development of territories and, in the future, bringing worldclass innovations to the market is supposed to be significant.

Practical Implications: The author proves the need to take into account the experience of other countries in creating research and educational centres, marketing relations between universities and business community in the regions and the use of state marketing in continuing the implementation of initiatives to transform the Russian higher school into the flagship of innovative development of the national economy.

Originality/value: The author's approach can become the basis of marketing decisions in creating a mechanism for long-term cooperation between universities that receive investment and businesses focused on the investigation of innovative products to ensure the trajectory of innovative development of the national economy in the interests of society as a whole.
\end{abstract}

Keywords: Marketing component, investments, universities, foreign experience, prospects.

JEL codes: $M 10$.

Paper type: Research article.

${ }^{1}$ Krasnodar Institute of Cooperation, Krasnodar, Russia, email: $\underline{\text { b14v@yandex.ru }}$ 


\section{Introduction}

Nowadays, significant changes are being made in the higher education establishments in Russia. These transformational changes are associated with ambitious tasks set for modern universities, according to which they should become the "locomotives" of the innovative development of the national economy, providing training of the specialists able to create innovations in priority sectors, form new markets and find promising niches in the world market for innovative products and services in order to increase the Pro-gradient growth of Russia's share in it. These tasks are set together with a number of other criteria in the adopted and ongoing national projects "Science" (Passport of the national project "Science" 2018) and "Education" (Passport of the national project "Education", 2019). These national projects provide funding for the transformation of higher education. Such solutions are considered to be a component of the state marketing that aims universities to create and promote innovations (Bondarenko et al., 2020c).

In addition to initiatives in the state marketing, which provide opportunities for increasing the attraction of state funding to leading universities (Bondarenko et al., 2019), it is significant to involve marketing of partnership between universities and business. It is aimed at private investment to universities in order to provide training of innovation-oriented specialists for modern companies, as well as conditions for creating new products by combining the potential of universities and business (Mitrofanova et al., 2017). Accordingly, it is relevant to investigate the issues of marketing component in attracting companies' investments to universities based on the foreign experience and practices acceptable for the implementation in Russian conditions.

\section{Materials and Methods}

Studying the foreign experience in the sphere of attracting investments into universities and finding financial mechanism in domestic conditions the author investigates the Russia's place in the ranking of the Global innovation index, discusses approaches to funding models of universities and analyses data on investments of business in different countries for scientists working in the scientific and educational organizations. Also, the author investigates the Russian models of universities, and propose a mechanism for their interaction with business in order to attract investment on mutually beneficial terms in the ideological paradigm of relationship marketing. The author used general scientific methods, such as the system analysis, comparative analysis and synthesis, and graphical interpretation of data.

\section{Discussion}

By describing the requirements for Russian universities, it is reasonable to note that their entry into the world ranking of TOP 5-100 has been initiated and is being 
implemented (Balashov and Khusainova, 2016). Leading Russian and foreign researchers also suggest to evaluate the rating performance indicators of universities on the base of certain indexes, which makes it possible to speak about the level of competitiveness of universities and, accordingly, their opportunities to attract investment (Ablameyko et al., 2013; Beizerov, 2016; Donetskaya, 2014; Kharchenko et al., 2013; Shevchenko and Loktyushina, 2016; Sheng-Ju Chan, 2016). Researchers note that there are three main approaches to financing universities abroad: formulabased financing, performance-based financing, and negotiated financing (Chernova $e t$ al., 2017).

In the use of the formula-based financing approach, the required amount of funds is calculated by the specific formula that includes indicators such as the number of students, the number of published works by university specialists, and some other criteria. When applying the performance-based financing model, it is necessary to have an agreement between the university and the state structure, which provides for the required performance in reaching goals by the university. The negotiation model is based on the existing image characteristics of the University (Bondarenko et al., 2020b). There is also an example to combine different models of university financing, this practice is considered to be the reasons for the decline in state funding of education and the need to find other sources of financing (Lisyutkin, 2017). Despite the interest of private investors in financing universities, currently in Europe, Japan and the United States, costs on higher education is about $1.3 \%$ of GDP, and about $1.1 \%$ of it comes from the state, while only $0.2 \%$ is private financing (Warden, 2018).

According to the Russian higher education system, researchers identify several promising models of universities. In the future, with high probability, universities will be actively presented in the Russian educational market and will attract investment to become the flagships of the innovative economic development and a place for training innovation-oriented specialists (Voronov et al., 2018). These promising models of universities typical for the Russian education market are shown in Figure 1.

Figure 1. Promising models of universities in the Russian educational market (Bondarenko et al., 2020).

\begin{tabular}{|l|l|}
\hline The research component prevails \\
\hline Corporate university & $\begin{array}{l}\text { Universities providing } \\
\text { infrastructure for research } \\
\text { projects }\end{array}$ \\
\hline $\begin{array}{l}\text { Center for professional } \\
\text { communities }\end{array}$ & $\begin{array}{l}\text { Universities - online } \\
\text { education platforms }\end{array}$ \\
\hline \multicolumn{2}{|l|}{ The educational component prevails } \\
\hline
\end{tabular}

Source: Author.

All the presented models of universities are interested in attracting investors and collaborations with them in marketing partnership in order to fulfil their tasks such as 
training innovative $\mathrm{HR}$, specialists for industrial companies and investigations and creating innovative products to the market together with partners.

\section{Results}

Since universities in Russia are faced the task to become agents of the innovative development in the national economic system, it is important first, to present the position of Russia in the world ranking on the Global innovation Index (Figure 2).

Figure 2. The Russia's position in the global innovation index (GII) ranking in 2015 and 2018 compared to other countries (GII2015, 2016; GII2018, 2019).

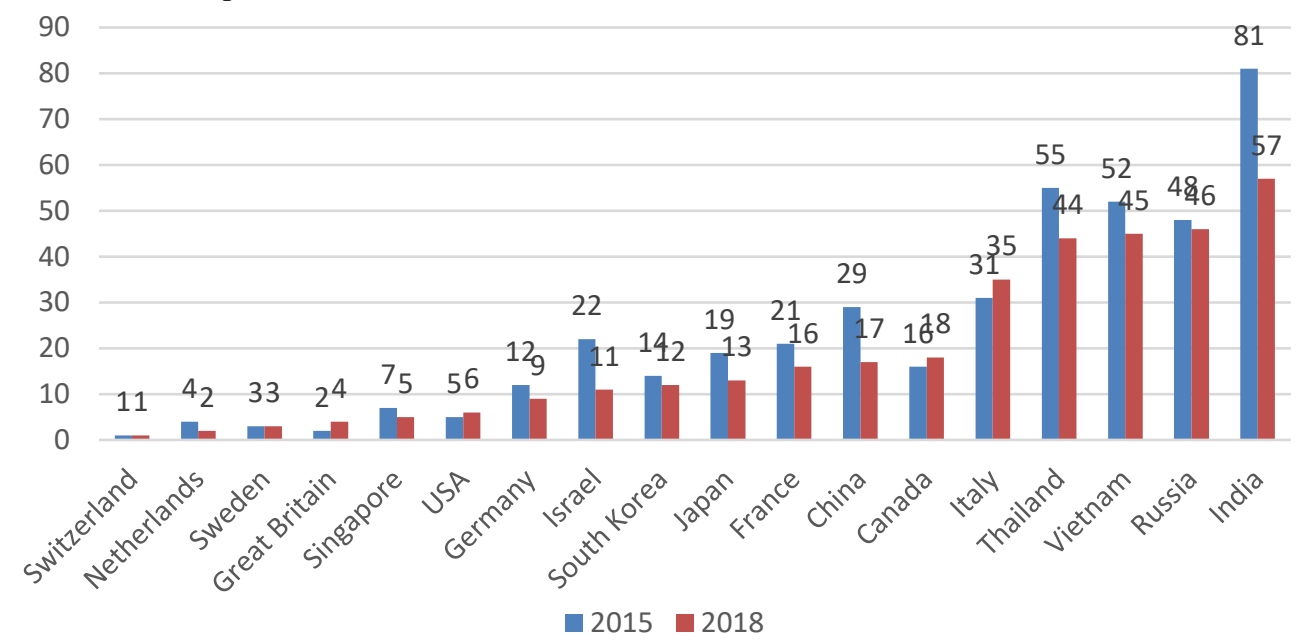

Source: Author.

According to these data the Russia's position has improved, but it occupies only the $46^{\text {th }}$ position, far behind China, South Korea, the United States, and the EU countries. Accordingly, Russian universities face great tasks, including attracting investment to increase the indicators of innovative development of the economy. Based on foreign experience in activating partnership between universities and business structures, we can note the growth of research and educational centres based on universities and the strengthening of their relationship with business (Maltsev and Mordvinova, 2016). For example, in this regard, industrial universities were created in the United States, which received and still receive funding based on close interaction with enterprises in the area of their localization (Maltsev and Mordvinova, 2016). These universities receive investments for the development and implement their investigations that contribute to the positive evolution of business in the region.

As part of the partnership marketing, companies in a number of countries are objectively aimed at financing universities to train qualified specialist for their own needs. Business investment involves training high-quality and competent professionals who can effectively work for the benefit of companies in the innovation- 
oriented economy. Abroad, the contribution of business to universities is tracked by deductions per one researcher working at the university. Information on such deductions in a number of countries is shown in Figure 3.

Figure 3. Companies' costs on university funding per one researcher per one year, US dollars (Naumova and Korobova, 2016).

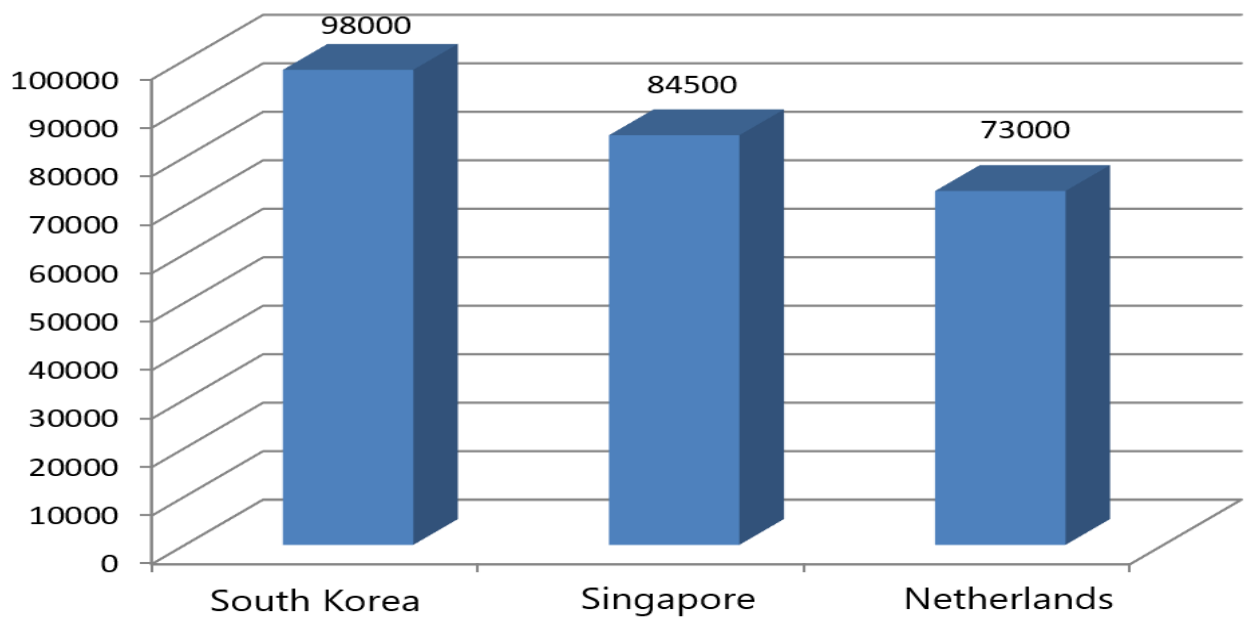

Source: Author.

In the countries that are significantly inferior to the conventional leaders listed above, such costs do not exceed 9 thousand US dollars per year. Russian businesses, in general, are interested in training specialists, however, it is necessary to create a mechanism that ensures systematic work on training profile specialists, as well as joint (between business and universities) commercialized innovations in demand in the markets.

In such conditions, the practice to create research and educational centres, which has already been tested abroad, is in demand. Such collaboration is seemed to be promising for industrial partners in Russian context in terms of marketing partnership between university centres and business. Practical steps to create research and education centres have already been implemented in a number of Russian regions. This mechanism is effective, since it contributes to solving problems of higher education, along with solutions beneficial for the region and obtaining visible effects for businesses that cooperate with universities in the innovative development and support of the researchers. Based on mutually beneficial cooperation in the research and education centres universities receive funding for research projects important to their regions, the national market and, in the future, for the development of certain niches in the world market. Also, they can train their graduates to work in practiceoriented innovative projects. 
Their industrial partners also get significant advantages in the training of profile specialists for their own needs, increasing the innovative component of their business, which contributes to the growth of their competitiveness. Also, universities' industrial partners can get institutional support from the authorities in the regions and scientific support from universities in creating and bringing innovative developments to the markets.

Accordingly, universities and business benefit from this marketing model of cooperation, as well as the population which receive opportunities both to get new knowledge and participate in creating innovations at new working places in the region. State authorities benefit from this cooperation, too, because this cooperation makes it possible to implement an innovative scenario for the development of the economy in the region where the scientific and educational centre is situated. This model of interaction between business and universities will help to attract private investment in solving the ambitious tasks facing higher education in Russia, based on a mutually beneficial marketing cooperation.

\section{Conclusion}

Summing up the study about the marketing component to attract investment into universities, taking into account the international experience, we can make a conclusion that the partnership model based on relationship marketing (if we take the European practice as a basis) and cooperation between business and universities, with the patronage from the state is prevailing in the world practice. In the American version, priorities are also shown in forming a model of long-term cooperation between universities of an entrepreneurial type and business in the region. Paternalism of the state authorities is shown in this case to a minimal extent. However, the beneficiaries are both the state and society.

In the Russian context, taking into account the traditionally leading role of the state in the reformation, development and innovation, the influence of state marketing in implementing adaptive changes in higher education, contributing to its transformation into an engine of the innovative development is supposed to be dominant. Also, for Russia, the mechanism of forming research and educational centres in the regions that contribute to the creation of innovative solutions for the development and, in the future, bringing world-class innovations to the market seems to be in demand. This practice helps to solve the problems facing higher school and allows business to significantly raise the level of the development and innovative solutions in the regions, along with the training of innovation-oriented specialist that contribute to the growth of business capitalization. 


\section{References:}

Ablameyko, S.V., Zhuravkov, M.D., Samokhval, V.V. 2013. Higher education Institutions of the CIS member countries in the world webometric rating: the analysis based on the profile of their activities. Higher education in Russia, 8-9, 25-31.

Balashov, A.I., Khusainova, V.M. 2016. The Project "5-100": the pursuit of global competitiveness or a tool to reset the national system of higher education? Economics and management, 10(132), 79-86.

Beizerov, V.A. 2016. University Competitiveness and world University rankings. Sociology of education, 6, 80-90.

Bondarenko, V.A., Kostoglodov, D.D., Manzhula, A.A. 2019. State marketing in promoting the innovative development of the economy and attracting investment. Financial Economics, 10, 351-357.

Bondarenko, V.A., Maksaev, A.A., Shumakova, I.A. 2020a. Issues of interrelation of marketing activity and model of University financing. Financial research, 1.

Bondarenko, V.A., Maksaev, A.A., Shumakova, I.A. 2020b. Possible functional spheres of the University President's activity in the implementation of the University's marketing strategy. Bulletin of the Belgorod University of Cooperation, Economics and law, 2(81), 224-234.

Bondarenko, V.A., Manzhula, A.A., Sagoyan, A.S. 2020c. Complexity of the innovative development of the economy and practical solutions to overcome them in the state marketing. Financial Economics, 2, 371-378.

Chernova, E.G., Akhobadze, T.D., Malova, A.S., Sultan, A.A. 2017. Models of financing education and efficiency of University activity. Issues of education, 3, 37-82.

Donetskaya, S.S. 2014. Analysis of the competitiveness of Russian universities in the world ranking. Higher education in Russia, 6, 20-31.

GII2015. 2016. The Global Innovation Index 2015: Effective Innovation Policies for Development. Available at: www.globalinnovationindex.org/about-gii\#reports.

GII2018. 2019. The Global Innovation Index 2018: Energizing the World with Innovation. Available at: www.globalinnovationindex.org/about-gii\#reports.

Kharchenko, E.V., Spitsyn, E.V., Voytash, L.A. 2013. Imperatives of increasing the competitiveness of Russian universities through the prism of international rating systems. Socio-economic phenomena and processes, 6(52), 148-153.

Lisyutkin, M.A. 2017. On possible reasons for the deterioration of the resource base of universities. The issues of education, 2, 74-94.

Maltsev, A.A., Mordvinova, A.E. 2016. Restructuring of old industrial regions of Europe: experience and problems. Manager, 3(61), 8-13.

Maltsev, A.A., Mordvinova, A.E. 2018. The American model of the revitalization of old industrial regions. Bulletin of the Russian University of peoples' friendship, Series: Economics, 1(26), 76-88.

Mayorova, T.V. 2013. Problems of financing higher education in the context of globalization. Theory and practice of service: Economy, social sphere, techniques. Available at: https://cyberleninka.ru/article/n/problem-finansirovaniya-vysshegoobrazovaniya-v-usloviyah-globalizatsii.

Mitrofanova, S.V., Demjanchenko, N.V., Novikov, S.V., Rudakova, O.V., Shmanev, S.V. 2017. The role and features of the enterprises' working conditions before and after the transition to market relations: a view from macroeconomic perspective. International Journal of Applied Business and Economic Research, 13(15), 63-72. 
Naumova, N.V., Korobova, O.V. 2016. Prospects for attracting investment in Russian universities. Models, systems, and networks in Economics, technics, nature, and society, 2(18), 54-61.

NPEDUCATION. 2018. Passport of the national project "Education". Available at: https://base.garant.ru/72192486/.

NPSCIENCE. 2018. Passport of the national project "Science". Available at: http://government.ru/projects/ selection/740/35565/.

Sheng-Ju, C. 2012. Enhancing Global Competitiveness: Enhancing Global Competitiveness: University Ranking Movement in the University Ranking Movement in Asia. Enhancing Global Competitiveness: Enhancing Global Competitiveness: University Ranking Movement in University Ranking Movement in Asia. Available at: http://www.ireg-observatory. org/ireg-6/presentation/shengju.pdf.

Shevchenko, D.A., Loktyushina, Yu.V. 2016. Webometrics Rating: indicator of quality and competitiveness of Russian universities in the World market of education. RSHU Bulletin, series: Economics, Management, Law, 2(4), 95-102.

Voronov, A.A., Garkovenko, V.E., Safonov, A.M., Kosnikov, S.N. 2018. Higher education competitiveness: definition, evaluation and ways of growth. European Research Studies Journal, S1(21), 525-534.

Warden, R. 2018. Funding for Europe's universities rising, but not enough. University world news, Europe edition, available at:

https://www.universityworldnews.com/post.php?story=20181020055821624. 